\title{
ASPEK YURIDIS PENERBITAN OBLIGASI DAERAH SEBAGAI SUMBER PEMBIAYAAN ALTERNATIF DI DAERAH
}

\author{
Made Gde Subha Karma Resen \\ Fakultas Hukum Universitas Udayana Bali \\ E-mail : subhakarma.skr@gmail.com
}

\begin{abstract}
ABSTRAK
Tulisan ini berjudul Aspek Yuridis Penerbitan Obligasi Daerah Sebagai Sumber Pembiayaan Alternatif di Daerah. Di era otonomi Daerah, pemerintah daerah memiliki peran penting dalam rangka mewujudkan pembangunan dan kesejahteraan di Daerah. Permasalahan yang sering terjadi adalah, tidak adanya pendanaan yang cukup, karena tidak semua pemerintah daerah memiliki surplus anggaran. Sehingga pemerintah Daerah diberikan peluang untuk mencari alternatif sumber pembiayaan sebagai wujud kemandirian daerah, salah satunya dengan cara menerbitkan obligasi daerah. Obligasi daerah juga membuka peluang bagi masyarakat di Daerah pada khususnya untuk ikut berpartisipasi berinvestasi.
\end{abstract}

Kata Kunci: Obligasi Daerah, Investasi, Kesejahteraan.

\section{ABSTRACT}

This paper titled Juridical Aspects of Municipal Bond Issuance as Alternative Sources of Financing in the Region. In the era of regional autonomy, local governments have an important role in order to realize development and prosperity in the region. The problem that often occurs is, the absence of adequate funding, because not all local authorities have a budget surplus. So that local authorities are given the opportunity to seek alternative sources of financing as a form of local independence, one of them by issuing municipal bonds. Municipal Bonds also provide an opportunity for people in the Region in particular to participate invest.

Keywords: Municipal Bonds, Investment, Welfare.

Pendahuluan

Prinsip otonomi daerah menggunakan prinsip otonomi yang seluas-luasnya, dalam arti daerah diberikan kewenangan mengurus dan mengatur semua urusan pemerintahan di luar yang menjadi urusan Pemerintah. Disadari bahwa tidak semua Pemerintah Daerah memiliki surplus anggaran untuk merealisasikan semua kebutuhan di daerah, bahkan kemungkinan terjadinya defisit anggaran sehingga diupayakan sumber- sumber pembiayaan atau pendanaan lain. Dalam hal keuangan, otonomi daerah pada hakekatnya memberikan kemandirian bagi daerah terutama dalam mencari alternatif-alternatif pendanaan untuk mempercepat proses pertumbuhan pembangunan dan kesejahteraan masyarakat di daerah. Salah satunya adalah dengan menerbitkan obligasi daerah, yang membuka kesempatan bagi masyarakat luas untuk 
berpartisipasi dalam rangka mempercepat

kesejahteraan.

Obligasi daerah yang merupakan wujud dari pinjaman daerah adalah salah satu sumber pembiayaan yang bertujuan untuk mempercepat pertumbuhan ekonomi di Daerah serta meningkatkan pelayanan kepada masyarakat. Pengelolaannya harus dilaksanakan secara benar, dalam rangka mendukung pelaksanaan amanat Undang-Undang No. 23 Tahun 2014 dan Undang-Undang No. 33 Tahun 2004 serta Undang-Undang No. 8 Tahun 1995 tentang Pasar Modal. Untuk menghindari dampak negatif bagi keuangan daerah serta stabilitas ekonomi dan moneter secara nasional.

Penerbitan Obligasi Daerah dilakukan melalui Penawaran Umum di pasar modal domestik. Daerah dimungkinkan untuk menerbitkan Obligasi Daerah dengan persyaratan tertentu, serta mengikuti peraturan perundang-undangan di bidang pasar modal dan memenuhi ketentuan nilai bersih maksimal Obligasi Daerah yang mendapatkan persetujuan Pemerintah. Segala bentuk akibat atau risiko yang timbul dari penerbitan Obligasi Daerah menjadi tanggung jawab Daerah sepenuhnya.

Dasar kebutuhan alternatifalternati pembiayaan karena, pengeluaran-pengeluaran publik yang dilakukan oleh pemerintah sangat penting untuk memenuhi kebutuhankebutuhan publik, baik itu infrastruktur fasilitas-fasilitas publik dan lain-lain, disesuikan dengan dinamika. Sebagimana di atur pada Pasal 300 Ayat (2) Undang-Undang Pemerintahan Daerah bahwa "Kepala daerah dengan persetujuan DPRD dapat menerbitkan obligasi Daerah untuk membiayai infrastruktur dan/atau investasi yang menghasilkan penerimaan Daerah setelah memperoleh pertimbangan dari Menteri dan persetujuan dari menteri yang menyelenggarakan urusan pemerintahan bidang keuangan." Kata "dapat" dalam pengaturan pasal tersebut memberi makna, bahwa penerbitan obligasi daerah bukanlah merupakan kewajiban, akan tetapi pilihan-pilihan yang dapat dilakukan oleh pemerintah daerah dalam rangka mendapatkan pembiayaan di Daerah, sebagai wujud dari kemandirian daerah. Sehingga pada akhirnya kebijakan pemerintah kembali sebagai penentu, sebagai jalan tengah (kearah yang lebih baik), terhadap penggunaan alternatif-alternatif pendanaan seperti penerbitan obligasi daerah sehingga memberikan kemanfaatan yang lebih besar bagi masyarakat di daerah pada khususnya.

\section{Urgensi Pengeluaran Publik Terhadap Pembangunan: Pembangunan (Investasi) vs Kesejahteraan (Konsumsi) di antara Kelangkaan Pembiayaan}

Banyak intelektual melihat ketidak sesuaian antara demokrasi dan pertumbuhan ekonomi dan pembangunan berdasarkan alasanalasan ekonomi maupun politik. Alasan ekonomi berhubungan dengan kenyataan bahwa pertumbuhan membutuhkan tersedianya surplus ekonomi bagi investasi. Surplus tersebut dapat diinvestasikan ataupun dikonsumsi. Oleh karena itu, satu-satunya jalan 
untuk meningkatkan surplus bagi investasi adalah dengan mengurangi konsumsi (Krisna, 2003). Argumentasinya adalah bahwa suatu Negara demokrasi tidak akan dapat menemukan kebijakan yang mudah, yang membatasi kesejahteraan atau konsumsi (misal: menekan upah riil) karena masyarakat yang menjadi imbas kebijakan juga merupakan pemilih (voter), dan mereka akan menghukum politisi pada saat pemilihan umum berikutnya melalui kotak suara.

Pandangan George Sorensen menanggapi bahwa, terdapat ketidak sesuaian dalam jangka pendek dan jangka panjang antara pertumbuhan ekonomi (investasi) dan kesejahteraan (konsumsi). Mereka yang mempunyai keberatan-keberatan ekonomi terhadap demokrasi memfokuskan pada terbujuknya para pemimpin demokrasi oleh elektoral untuk meningkatkan kesejahteraan dan, akibatnya, rendahnya tingkat pertumbuhan. Tindakan mereka membahayakan seluruh landasan bagi peningkatan kesejahteraan dalam jangka panjang. Selanjutnya dalam literatur ekonomi politik, Amartya Sen berpendapat bahwa demokrasi dapat menjadi salah satu unsur penentu dalam pertumbuhan ekonomi dan pengurangan kemiskinan. Melihat contoh tragedi kelaparan pada era tahun 80-an di China, yang menewaskan puluhan ribu penduduk. Bahwa tragedi kelaparan tidak mungkin terjadi di negara-negara yang menjunjung tinggi demokrasi (Knopf, 1999). Amartya Sen berpendapat bahwa demokrasi dapat menjadi alat yang penting bagi pertumbuhan ekonomi, dan pengurangan kemiskinan dan bahkan perlindungan dan pemenuhan hak-hak dasar masyarakat (Yudhatama, 2007).

Citasi-citasi tersebut di atas, menggambarkan betapa rumitnya menentukan prioritas antara pembangunan dan kesejahteraan, terkadang salah satu menjadi yang diutamakan di antara yang lain, karena dihadapkan pada kelangkaan atau keterbatasan pembiayaan. Pada ilmu ekonomi hal ini merupakan kewajaran, konsep ilmu ekonomi sebagaimana disampaikan oleh Richard A. Posner, Welter J. Wessels (Fajar Sugianto, 2013), pada dasarnya mempelajari bagaimana perilaku manusia berdasarkan pikiran rasional menentukan pilihan (choice) terbaik di tengah kelangkaan (scarcity), tentu saja untuk peningkatan dan perbaikan (maximization). Sehingga suatu pilihan tidak dapat dipisahkan dari konsep kelangkaan (Sugianto, 2013,).

Scarcity sebagaimana tersebut di atas oleh Robert L. Heilbroner dikatakan sebagai the economic problem, pernyataannya sebagai berikut:

"To be sure, the economic problem itself that is, the need to struggle for existence derives ultimately from the scarcity of nature. If there were no scarcity, goods would be as free as air, an economics, at least in one sense of the word, would cease to exist as a social preoccupation." (Heilbroner, 1962)

Dapat dipahami bahwa permasalahan ekonomi baik itu pembangunan dan kesejahteraan, tidak terlepas dari kelangkaan (sumber daya alam, modal, skill). 
Jika tidak terdapat kelangkaan setiap orang akan bebas menggunakan, menjadi sebuah "keasikan sosial."

Masyarakat merupakan salah satu pilar demokrasi yang kuat, masyarakat dapat mempengaruhi kebijakan-kebijakan publik melalui mekanisme politik maupun partisipasi dalam pembahasannya. Berikut akan ditunjukkan riset dan survei yang dilakukan oleh Power, Welfare and Democracy Project (PWD). Tujuan dari survei adalah mengevaluasi tantangan dan peluang demokrasi di Indonesia berbasis pada kerangka David Beetham sebagai pijakan dasar. Beetham mendefinisikan demokrasi sebagai

Grafik 1 : Aktor yang terlibat dalam pembahasan isu publik

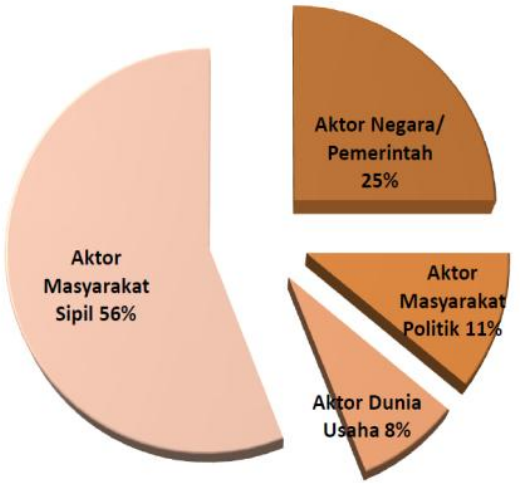

Sumber: PWD, 2014:11.

Isu pembangunan dan kesejahteraan tetap menjadi permasalahan yang tidak ada ujung pangkal, hal tersebut masih dalam tataran wacana dan regulasi, belum optimal pada tataran implementasi. Masih terdapat pelayanan publik terkait kesejahteraan yang belum tuntas terselesaikan, meskipun Negara Indonesia menganut konsepsi Negara kesejahteraan (welfare state) yang menempatkan peran aktif negara terhadap persoalan kesejahteraan rakyat. Riawan Tjandra mengungkapkan konsep welfare state secara ideologis dinilai paling sesuai "kontrol popular terhadap urusan publik dan politis berbasis persamaan hak warga negara". Survei ini telah dilakukan sebanyak 2 (dua) kali 2003/2004 dan 2007.Dalam ringkasan eksekutifnya menunjukkan bahwa masyarakat merupakan aktor yang paling sering membahas isu-isu publik dengan angka 56\% lebih tinggi dibandingkan aktor yang lain seperti; aktor Negara/pemerintah (25\%), aktor masyarakat politik (11\%) dan aktor dunia usaha (8\%), disajikan dalam grafik berikut ini. 
yang lebih tinggi yaitu 55,00\% dari pada pembangunan ekonomi dengan angka $28,10 \%$, selanjutnya diikuti isu hak kewarganegaraan $13,80 \%$ dan isu lain-lain 3,10\%. Isu-isu publik tersebut merupakan harapan masyarakat untuk dipenuhi oleh Negara/pemerintah.

Terlepas dari isu-isu publik tersebut, tarik menarik antara pembangunan dan kesejahteraan, merupakan problematika tersendiri yang dihadapi oleh pemerintah dalam mengambil kebijakan dalam suasana kelangkaan, karena bagaimanapun persoalan tersebut kembali pada seberapa banyak ketersediaan anggaran pemerintah untuk mendanai 2 (dua) kutub yang mengharapkan untuk diprioritaskan, sehingga tidak salah dapat dikatakan bahwa pengeluaran publik menjadi urgen bagi suatu Negara ataupun daerah diera otonomi ini.
Peran strategis pemerintah dalam perekonomian suatu Negara, dapat diamati dari peranannya dalam pembangunan. Sebagai contoh penelitian yang dilakukan pada Negara-negara ASEAN, melalui pengaruh pengeluaran atau pembiayaan publik terhadap perekonomian dan pengembangan sumber daya manusia (SDM). Pembagian pengeluaran publik yang didasarkan pada pengembangan SDM dan kesinambungan pertumbuhan ekonomi terdiri dari: (1) indikator sosial berupa Indeks Pembangunan Manusia (IPM) atau indeks kualitas hidup lainnya, dan (2) indikator ekonomi berupa PDB, laju pertumbuhan ekonomi, dan PDB per kapita riil.

Tabel 1:

PDB per Kapita dan IPM Negara ASEAN Tahun 2012 (Akhir Lubis,2011)

\begin{tabular}{|c|c|c|c|}
\hline NO. & NEGARA & $\begin{array}{c}\text { PDB PER KAPITA } \\
\text { (US\$/JIWA) }\end{array}$ & IPM \\
\hline 1. & Singapura & $46,241.00$ & 0,895 \\
\hline 2. & Brunei Darussalam & $41,127.00$ & 0,855 \\
\hline 3. & Malaysia & $10,381.00$ & 0,769 \\
\hline 4. & Thailand & $5,474.00$ & 0,690 \\
\hline 5. & Indonesia & $3,557.00$ & 0,629 \\
\hline 6. & Filipina & $2,588.00$ & 0,654 \\
\hline 7. & Vietnam & $1,596.00$ & 0,617 \\
\hline 8. & Laos & $1,399.00$ & 0,543 \\
\hline 9. & Kamboja & 943.00 & 0,543 \\
\hline 10. & High & $41,061.85$ & $>0,710$ \\
\hline 11. & Middle & $4,587.61$ & $>0,536$ \\
\hline 12. & Low & 582.47 & $>0,297$ \\
\hline
\end{tabular}

Sumber: World Bank dan UNDP, 2013

Tabel di atas menunjukkan bahwa negara-negara ASEAN terbagi kedalam tiga kelompok yaitu: (1) negara dengan penghasilan tinggi dan IPM tinggi yaitu Singapura dan Brunei Darussalam; (2) negara dengan penghasilan menengah dan IPM menengah yaitu Malaysia, Thailand, Indonesia, dan Filipina; dan (3) negara dengan penghasilan rendah dan IPM rendah yaitu Vietnam, Laos, dan Kamboja. 
Grafik 3:

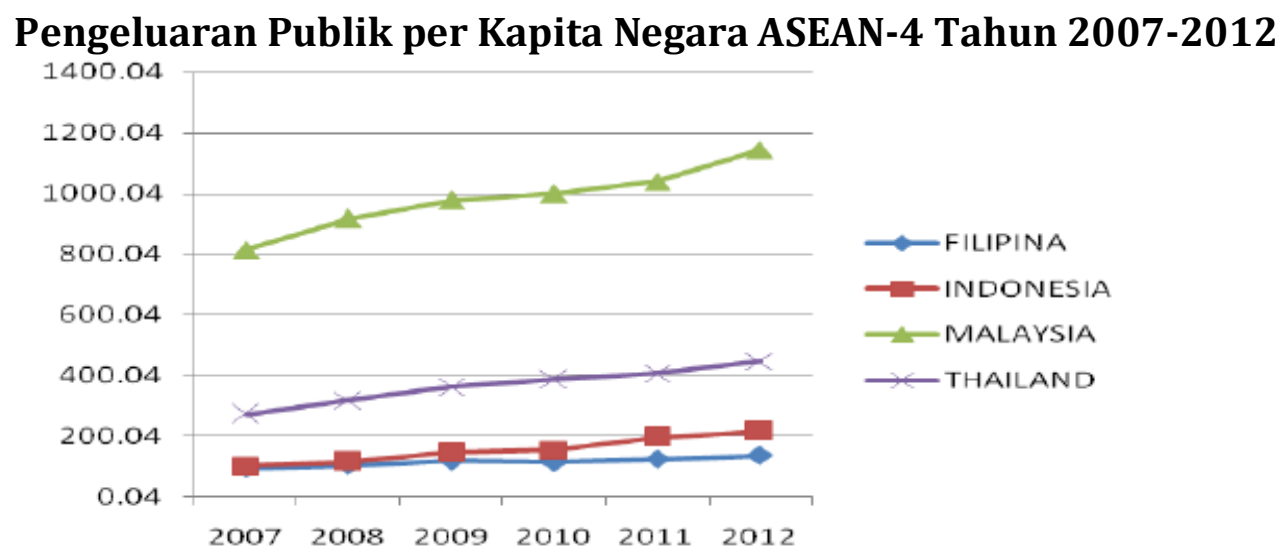

Sumber: Asian Development Bank, 2012.

Pada grafik 3 menunjukkan keempat negara yang menjadi fokus penelitian tersebut kurang lebih mempunyai strategi yang sama dalam menerapkan regulasi dan pengalokasian anggaran pengeluaran publik, yang menunjukkan bahwa pengeluaran publik per kapita keempat negara selama kurun waktu 2007 sampai dengan 2012 mempunyai trend yang meningkat.

Berdasarkan hasil penelitian tersebut di dapat kesimpulan bahwa pengeluaran publik dapat meningkatkan pembangunan melalui indikator IPM dan pertumbuhan ekonomi di Negara-Negara ASEAN-4. Pengeluaran publik bidang pendidikan dan kesehatan dapat meningkatkan kualitas SDM melalui konsumsi nutrisi yang baik, partisipasi pendidikan, dan kemudahan akses terhadap kesehatan sehingga setiap individu mempunyai ketahanan fisik, kemampuan, pengetahuan, dan keterampilan sebagai modal dasar manusia (human capital) dalam aktivitas ekonomi baik sebagai tenaga kerja maupun wirausaha.

Pengeluaran publik bidang infrastruktur membuka akses perdagangan yang semakin luas melalui pembangunan sarana dan prasarana yang dapat mengakomodasi semua kepentingan aktivitas ekonomi masyarakat yang terintegrasi, serta dampak ekonomis yang ditimbulkan dari meningkatnya pendapatan perkapita adalah meningkatnya daya beli dan tingginya tingkat konsumsi masyarakat sehingga akan meningkatkan permintaan agregat atas komoditas tersebut yang akan mendorong terjadinya investasi yang akhirnya dapat menciptakan pertumbuhan ekonomi.

Obligasi Daerah sebagai Sumber Alternatif Pembiayaan di Daerah

Setelah mencermati urgensi pengeluaran publik bagi pembangunan, menjadi penting diera otonomi daerah dicari alternatif-alternatif pendanaan yaitu dengan menerbitkan obligasi daerah untuk pembiayaan pembangunan di Daerah, untuk mengantisipasi kelangkaan atau keterbatasan pendanaan atau pembiayaan, karena pada masingmasing daerah memiliki karakter beranekaragam terkait dengan pembiayaan-pembiayaan publik yang dilakukan oleh pemerintah 
daerah berdasarkan kebutuhan daerahnya. Dasar hukum sumber pendanaan Pemerintah Daerah melalui pinjaman daerah sesungguhnya telah diatur sejak diberlakukannya UndangUndang No. 5 Tahun 1974 tentang Pokok-pokok Pemerintahan di Daerah, serta perubahan-perubahannya Undang-Undang No. 22 Tahun 1999 yang kemudian diamandemen dengan Undang-Undang No. 32 Tahuh 2004 tentang Pemerintahan serta sebagaimana terakhir dicabut dengan diundangkannya Undang-Undang No. 23 Tahun 2014 tentang Pemerintahan Daerah, serta Undang-Undang No. 33 Tahun 2004 tentang Perimbangan Keuangan Pusat Daerah. Melalui Undang-Undang No. 33 Tahun 2004 pemerintah daerah baru dapat diperbolehkan untuk mengeluarkan obligasi, namun hanya untuk membiayai investasi sektor publik yang menghasilkan penerimaan dan memberikan manfaat bagi masyarakat.

Istilah obligasi berasal dari bahasa Belanda, yaitu "obligatie" atau "verplitchting" atau "obligaat", yang berarti kewajiban yang tidak dapat ditinggalkan, atau surat utang suatu pinjaman Negara atau daerah atau perseroan dengan bunga tetap untuk pemegang. Pada Kamus hukum Sudarsono, obligasi diberikan dua pengertian. Obligasi adalah surat pinjaman dengan bunga tertentu dari pemerintah yang dapat diperdagangkan atau diperjualbelikan. Obligasi adalah surat utang berjangka(waktu) lebih dari satu tahun dan memiliki suku bunga tertentu, dimana surat tersebut dikeluarkan oleh perusahaan untuk menarik dana dari masyarakat guna menutup pembiayaan perusahaan (Widjaja \& Jono, 2006).
Berdasarkan UndangUndang No. 33 Tahun 2004, pengertian dari Pinjaman Daerah adalah semua transaksi yang mengakibatkan Daerah menerima sejumlah uang atau menerima manfaat yang bernilai uang dari pihak lain sehingga Daerah tersebut dibebani kewajiban untuk membayar kembali. Adapun pengertian Obligasi Daerah adalah Pinjaman Daerah yang ditawarkan kepada publik melalui penawaran umum di pasar modal.

Pengaturan tentang obligasi sebagai sumber pembiayaan pada Undang-Undang No. 23 Tahun 2014 dapat dicermati pada pasal-pasal berikut ini:

Pasal 300

(1) Daerah dapat melakukan pinjaman yang bersumber dari Pemerintah Pusat, Daerah lain, lembaga keuangan bank, lembaga keuangan bukan bank, dan masyarakat.

(2) Kepala daerah dengan persetujuan DPRD dapat menerbitkan obligasi Daerah untuk membiayai infrastruktur dan/atau investasi yang menghasilkan penerimaan Daerah setelah memperoleh pertimbangan dari Menteri dan persetujuan dari menteri yang menyelenggarakan urusan pemerintahan bidang keuangan.

Pasal 302

(1) Ketentuan lebih lanjut mengenai pinjaman Daerah diatur dengan peraturan pemerintah.

(2) Peraturan pemerintah sebagaimana dimaksud pada 
ayat (1) paling sedikit mengatur:
a. persyaratan bagi Daerah dalam melakukan pinjaman;
b. penganggaran kewajiban pinjaman Daerah yang jatuh tempo dalam APBD;
c. pengenaan sanksi dalam hal Daerah tidak memenuhi kewajiban membayar pinjaman;
d. tata cara pelaporan posisi kumulatif pinjaman dan kewajiban pinjaman setiap semester dalam tahun anggaran berjalan;
e. persyaratan penerbitan obligasi Daerah serta pembayaran bunga dan pokok obligasi; dan
f. pengelolaan obligasi Daerah yang mencakup pengendalian risiko, penjualan dan pembelian obligasi serta pelunasan dan penganggaran dalam APBD.

Selain diatur dalam Undang-Undang No. 23 Tahun 2014, perihal obligasi daerah secara lebih luas diatur dalam beberapa aturan hukum di antaranya:

1. Undang-Undang Nomor 8 Tahun 1995 tentang Pasar Modal;

2. Undang-Undang Nomor 33 Tahun 2004 tentang Perimbangan Keuangan antara Pemerintah Pusat dan Pemerintahan Daerah;

3. Peraturan Pemerintah No. 54 Tahun 2005 tentang Pinjaman Daerah, telah dirubah dengan Peraturan Pemerintah No. 30 Tahun 2011 tentang Pinjaman Daerah

4. Peraturan Menteri Dalam Negeri No. 21 Tahun 2011 tentang Perubahan Kedua Atas
Peraturan Menteri Dalam Negeri Nomor 13 Tahun 2006 Tentang Pedoman Pengelolaan Keuangan Daerah,

5. Peraturan Menteri Keuangan Republik Indonesia No. 111/PMK.07/2011 tentang Tata Cara Penerbitan dan Pertanggungjawaban Obligasi Daerah

6. Keputusan Ketua Badan Pengawas Pasar Modal Dan Lembaga Keuangan Nomor: Kep-692/Bl/2011 Tentang Pedoman Mengenai Bentuk Dan Isi Pernyataan Pendaftaran Dalam Rangka Penawaran Umum Obligasi Daerah Ketua Badan Pengawas Pasar

7. Keputusan Ketua Badan Pengawas Pasar Modal dan Lembaga Keuangan Nomor: Kep-65/BL/2007 tentang Pedoman Penyusunan Surat Kepala Daerah di Bidang Akuntansi dalam Rangka Penawaran Umum Obligasi Daerah,

8. Keputusan Ketua Bdan Pengawasan Pasar Modal dan Lembaga Keuanan Nomor: Kep-67/BL/2007 tentang Pedoman Mengenai Bentuk dan Isi Prospektus Dalam Rangka Penawaran Umum Obligasi Daerah.

Undang-Undang No. 33 Tahun 2004 tentang Perimbangan Keuanganan antara Pemerintah Pusat dan Pemerintah Daerah, menjadi landasan hukum dan menjadi acuan bagi Pemerintah 
Daerah dalam menerbitkan obligasi daerah, beberapa pasal mengatur sebagai berikut:

Pasal 51 Ayat (1) dan (3)

1) Pinjaman Daerah bersumber dari:
a. Pemerintah;
b. Pemerintah Daerah lain;
c. lembaga keuangan bank;
d. lembaga keuangan bukan bank; dan
e. masyarakat.

2)

3) Pinjaman Daerah yang bersumber dari masyarakat sebagaimana dimaksud pada ayat (1) huruf e berupa Obligasi Daerah diterbitkan melalui pasar modal.

Pasal 52 Ayat (1) dan (4):

1) Jenis Pinjaman terdiri atas:
a. Pinjaman Jangka Pendek;
b. Pinjaman Jangka Menengah; dan
c. Pinjaman Jangka Panjang.

2)

3)

4) Pinjaman Jangka Panjang sebagaimana dimaksud pada ayat (1) huruf c merupakan Pinjaman Daerah dalam jangka waktu lebih dari satu tahun anggaran dan kewajiban pembayaran kembali pinjaman yang meliputi pokok pinjaman, bunga, dan biaya lain harus dilunasi pada

Umumnya obligasi diterbitkan untuk jangka waktu yang panjang, bisa mencapai 5 (lima) tahun.

Pasal 53 Ayat (3) dan (4) mengatur bahwa, Pinjaman Jangka Panjang dipergunakan untuk membiayai proyek investasi yang menghasilkan penerimaan. Pinjaman Jangka Menengah dan Jangka Panjang wajib mendapatkan persetujuan DPRD. Dari penjelas undang-undang tersebut, dijelaskan bahwa dana dari penerbitan obligasi daerah sebagai salah satu bentuk pinjaman jangka panjang, yang hanya boleh digunakan untuk membiayai proyek investasi (pembangunan prasarana dan sarana) yang menghasilkan penerimaan. Untuk mendapatkan pinjaman tersebut, Pemerintah Daerah harus mendapatkan persetujuan dari pihak DPRD, termasuk dalam hal pinjaman tersebut diteruspinjamkan kepada BUMD.

Pasal 54 menegaskan bahwa, dalam melakukan pinjaman, Daerah wajib memenuhi persyaratan:

a. jumlah sisa Pinjaman Daerah ditambah jumlah pinjaman yang akan ditarik tidak melebihi 75\% (tujuh puluh lima persen) dari jumlah penerimaan umum APBD tahun sebelumnya;

b. rasio kemampuan keuangan Daerah untuk mengembalikan pinjaman ditetapkan oleh Pemerintah;

c. tidak mempunyai tunggakan atas pengembalian pinjaman yang berasal dari Pemerintah.

Pasal ini mengatur dan menegaskan tentang syarat atau batasan yang harus dipenuhi daerah dalam memperoleh pinjaman, termasuk dengan cara menerbitkan obligasi daerah. syarat dan pembatasan tersebut merupakan salah satu prudential principle/prinsip kehati-hatian yang harus selalu diperhatikan dalam setiap melakukan perencanaan dalam memperoleh pinjaman, termasuk juga 
menetapkan aset-aset daerah yang akan dijadikan jaminan untuk mendapatkan pinjaman jangka panjang (obligasi). Pasal 55 Ayat (2) dan (3) menegaskan bahwa, Pendapatan Daerah dan/atau barang milik Daerah tidak boleh dijadikan jaminan Pinjaman Daerah. Proyek yang dibiayai dari Obligasi Daerah beserta barang milik Daerah yang melekat dalam proyek tersebut dapat dijadikan jaminan Obligasi Daerah.

Pada dasarnya tidak semua asetaset daerah dan pendapatan daerah diperkenankan untuk dijadikan jaminan atas pinjaman daerah, akan tetapi dalam hal penerbitan obligasi, Pemerintah Daerah dapat menjaminkan asetnya yang melekat dalam proyek pembangunan/investasi sebagai bentuk penyertaan pemerintah.

Pada pasal 57 juga ditetapkan bahwa, obligasi daerah harus diterbitkan dalam mata uang rupiah, dengan memenuhi ketentuan yang diatur dalam pasal 54 dan pasal 55 sebagaimana tersebut di atas, beserta peraturan perundang-undangan di bidang pasar modal. Ditegaskan pula bahwa hasil penjualan obligasi harus digunakan untuk membiayai investasi sektor public yang selain dapat memberikan manfaat bagi masyarakat juga harus menghasilkan penerimaan guna membiayai kewajiban bunga dan pokok obligasi daerah yang membiayai proyek-proyek tersebut. Jika dari penerimaan atas proyek pembangunan yang dibiayai dari obligasi daerah, setelah disisihkan untuk membayar kewajiban bunga dan pokok obligasi terdapat kelebihan, maka kelebihan tersebut harus disetorkan ke kas daerah sebagai salah satu bentuk penerimaan daerah.
Beberapa pasal yang sangat penting harus dicermati bahwa (Pasal 58), dalam hal Pemerintah Daerah menerbitkan obligasi daerah, kepala daerah terlebih dahulu mendapatkan persetujuan DPRD dan Pemerintah, dan ditetapkan berdasarkan Peraturan Daerah. Persetujuan penerbitan obligasi daerah harus diberikan atas nilai bersih maksimal obligasi daerah yang dapat diterbitkan pada saat penetapan APBD. Adapun yang dimaksud dengan nilai bersih adalah tambahan atas nilai nominal obligasi daerah yang beredar. Tambahan nilai nominal ini merupakan selisih antara nilai nominal obligasi daerah yang diterbitkan dengan nilai nominal obligasi yang ditarik kembali dan dilunasi sebelum jatuh tempo dan obligasi yang dilunasi pada saat jatuh tempo selama satu tahun anggaran. Sebagai wujud kemandirian daerah, sebagaimana diatur dalam Pasal 59 bahwa, Pemerintah Pusat tidak menjamin obligasi daerah (Okta dan David Kaluge, 2011). pemerintah Provinsi/Kabupaten/Kota harus bertanggungjawab secara penuh atas obligasi yang diterbitkannya, karena pemerintah pusat tidak memberikan jaminan dalam bentuk apapun, baik atas kewajiban bunga maupun pokok obligasi daerah.

Dalam rangka melaksanakan amanat Pasal 49 Peraturan Pemerintah No. 30 Tahun 2011 tentang Pinjaman Daerah, telah ditetapkan Peraturan Menteri Keuangan No. 111/PMK. 07/2012 tentang Tata Cara Penerbitan dan Pertanggungjawaban Obligasi 
Daerah (www.djpk.kemenkeu.go.id). Berdasarkan peraturan perundangan, Pemerintah daerah dapat menerbitkan obligasi daerah untuk membiayai kegiatan atau beberapa kegiatan investasi prasarana dan/atau sarana dalam rangka penyediaan pelayanan publik yang menghasilkan penerimaan bagi APBD yang diperoleh dari pungutan atas penggunaan prasarana dan/atau sarana tersebut.

Persyaratan yang wajib dipenuhi oleh pemerintah daerah sebelum menerbitkan obligasi daerah adalah sebagai berikut:

a. Audit terakhir atas Laporan Keuangan Pemerintah Daerah mendapat opini Wajar Dengan Pengecualian atau Wajar Tanpa Pengecualian;

b. Jumlah kumulatif pinjaman, yaitu jumlah sisa pinjaman daerah ditambah jumlah pinjaman yang akan ditarik tidak melebihi $75 \%$ (tujuh puluh lima persen) dari jumlah penerimaan umum APBD tahun sebelumnya;

c. Rasio kemampuan keuangan daerah untuk mengembalikan pinjaman atau Debt Service Coverage Ratio (DSCR) yaitu paling sedikit 2,5 (dua koma lima);

d. Jumlah defisit APBD sesuai dengan yang ditetapkan oleh Menteri Keuangan; dan

e. Persetujuan DPRD yang meliputi nilai bersih maksimal obligasi daerah, ketersediaan pembayaran pokok dan bungan, dan ketersediaan pembayaran segala biaya yang timbul dari penerbitan obligasi daerah. 
Pengelolaan obligasi daerah dilaksanakan oleh unit yang ditunjuk oleh gubernur, bupati atau walikota. Unit tersebut berupa satuan kerja yang sudah ada atau satuan kerja yang baru, dimana satuan kerja tersebut memiliki struktur organisasi, perangkat kerja, dan kapasitas sumber daya manusia untuk melaksanakan fungsi pengelolaan obligasi daerah. Pemerintah daerah wajib mendapat persetujuan prinsip dari Menteri Keuangan atas rencana penerbitan obligasi daerah sebelum proses di pasar modal. Penerbitan obligasi daerah dalam APBD sesuai kemampuan keuangan daerah untuk pembayaran pokok obligasi daerah. Gubernur, bupati, atau walikota wajib menyampaikan Peraturan Daerah mengenai penerbitan obligasi daerah kepada otoritas di bidang pasar modal dengan tembusan kepada Direktur Jenderal Perimbangan Keuangan, sebelum pernyataan efektif Obligasi Daerah. Pemerintah daerah wajib menyampaikan laporan

pelaksanaan pengelolaan Obligasi
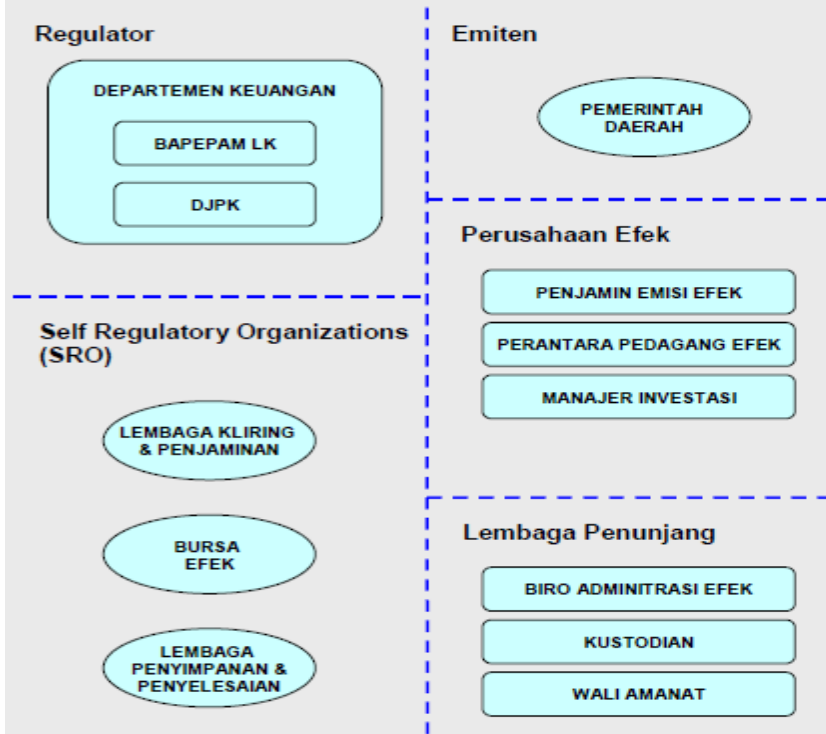

Pemegang Efek

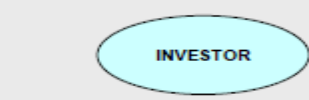

Profesi Penunjang

AKUNTAN PUBLIK

NOTARIS KNSULTAN HUKUM

PERUSAHAAN PENILAI

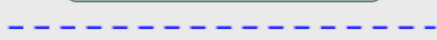

Pihak Lain Yang Terlibat

LEMBAGA PEMERINGKAT EFEK

PENYEDIA PENGUATAN KREDIT PENASIHAT INVESTAS

hanya dapat dilakukan di pasar modal domestik dan dalam mata uang rupiah serta dilaksanakan sesuai dengan ketentuan peraturan perundangundangan di bidang pasar modal. Pemerintah daerah bertanggung jawab atas segala resiko yang timbul akibat dari penerbitan obligasi daerah termasuk wajib membayar pokok dan bunga obligasi daerah pada saat jatuh tempo. Setiap tahun pemerintah daerah wajib mengalokasikan dana cadangan

Tabel 2: Pihak-pihak yang terkait dengan obligasi daerah

Sumber: Direktorat Jenderal Perimbangan Keuangan Departemen Keuangan, 2007.
Daerah kepada Menteri Keuangan c.q. Direktur Jenderal Perimbangan Keuangan, apabila pemerintah daerah tidak menyampaikan laporan tersebut, Menteri Keuangan dapat menunda penyaluran Dana Perimbangan.

Pihak-pihak yang terlibat di dalam penerbitan obligasi, akan diterangkan pada tabel berikut : 
Regulator, adalah lembaga/instansi pemerintah yang memiliki kewenangan untuk mengatur dan mengawasi pelaksanaan penawaran umum obligasi daerah di pasar modal. Pengawasan tersebut merupakan tanggung jawab Departemen Keuangan dimana secara prakteknya dilakukan oleh Badan Pengawas Pasar Modal-Lembaga Keuangan, dan Direktorat Jenderal Perimbangan Keuangan.

a) Direktorat Jenderal Perimbangan Keuangan (DJPK), merupakan unsur di dalam Departemen Keuangan, yang bertindak atas nama Menteri Keuangan untuk mengevaluasi dan memberikan persetujuan atas rencana penerbitan obligasi daerah yang diajukan oleh pemerintah daerah serta mengawasi pengelolaan obligasi daerah, sesuai dengan kerangka kerja pinjaman daerah seperti diatur dalam PP 54/2005.

b) Bapepam Lembaga Keuangan (Bapepam-LK), adalah Badan Pengawas Pasar Modal dan Lembaga Keuangan yang bertugas untuk melakukan pembinaan, pengaturan dan pengawasan Pasar Modal dengan tujuan mewujudkan terciptanya kegiatan Pasar Modal yang teratur, wajar, dan efisien serta melindungi kepentingan pemodal dan masyarakat.

Self Regulatory Organizations (SRO), merupakan lembaga/organisasi yang berwenang untuk mengeluarkan peraturan bagi kegiatan usahanya. Di pasar modal, SRO terdiri dari bursa efek, lembaga kliring dan penjaminan, serta lembaga penyimpanan dan penyelesaian.

a) Bursa Efek, adalah pihak yang menyelenggarakan dan menyediakan sistem dan atau sarana untuk mempertemukan penawaran jual dan beli efek pihakpihak lain dengan tujuan memperdagangkan efek di antara mereka.

b) Lembaga Kliring dan Penjaminan, adalah pihak yang menyelenggarakan jasa kliring dan penjaminan penyelesaian transaksi bursa. Di Indonesia, lembaga kliring dan penjaminan yang telah mendapat izin dari Bapepam LK adalah PT. Kliring Penjaminan Efek Indonesia (PT. KPEI).

c) Lembaga Penyimpanan dan Penyelesaian, adalah pihak yang menyelenggarakan kegiatan kustodian sentral bagi bank kustodian, perusahaan efek, dan pihak lain. Di Indonesia, lembaga penyimpanan dan penyelesaian yang telah mendapat izin dari Bapepam dan LK adalah PT. Kustodian Sentral Efek Indonesia (PT. KSEI).

Emiten, merupakan pihak yang melakukan penawaran umum. Dalam kaitannya dengan obligasi daerah, pihak yang menjadi emiten adalah pemerintah daerah. Pemegang Efek, adalah investor atau pihak yang menanamkan modalnya dalam bentuk pemberian pinjaman 
kepada pemerintah daerah dalam bentuk obligasi daerah.

Perusahaan Efek, adalah perusahaan yang mempunyai aktivitas sebagai penjamin emisi efek, perantara pedagang efek, manajer investasi, atau gabungan dari ketiga kegiatan tersebut.

a) Penjamin Emisi Efek, adalah pihak yang membuat kontrak dengan emiten untuk melakukan penawaran umum bagi kepentingan emiten dengan atau tanpa kewajiban untuk membeli sisa efek yang tidak terjual.

b) Perantara Pedagang Efek, adalah pihak yang melakukan kegiatan usaha jual beli efek untuk kepentingan sendiri atau pihak lain.

c) Manajer Investasi, adalah pihak yang kegiatan usahanya mengelola portofolio efek untuk para nasabah atau mengelola portofolio investasi kolektif untuk sekelompok nasabah, kecuali perusahaan asuransi, dana pensiun dan bank yang melakukan sendiri kegiatan usahanya berdasarkan peraturan perundang-undangan yang berlaku.

Lembaga Penunjang, merupakan pihak-pihak penunjang terlaksananya pelaksanaan penawaran umum, yang terdiri dari biro administrasi efek, kustodian dan wali amanat.

a) Biro Administrasi Efek, adalah pihak yang berdasarkan kontrak dengan emiten melaksanakan pencatatan pemilikan efek dan pembagian hak yang berkaitan dengan efek.

b) Kustodian, adalah pihak yang memberikan jasa penitipan efek dan harta lain berkaitan dengan efek serta jasa lain, termasuk menerima deviden, bunga, dan hak lain, menyelesaikan transaksi efek, dan mewakili pemegang rekening yang menjadi nasabahnya.

c) Wali Amanat, adalah pihak yang mewakili kepentingan pemegang efek bersifat utang (termasuk obligasi daerah). Penunjukan Wali Amanat dilakukan melalui perjanjian bersama seluruh pihak pada penerbitan obligasi daerah. Wali amanat bertugas untuk mengendalikan seluruh aspek-aspek administratif penerbitan obligasi daerah, termasuk memastikan bahwa penerbitan obligasi daerah telah sesuai dengan ketentuan dan persyaratan pada perjanjian obligasi daerah.

Profesi Penunjang, merupakan pihak-pihak yang karena profesinya, turut menunjang terlaksananya penawaran umum di pasar modal. Untuk melakukan kegiatan di bidang pasar modal, profesi penunjang pasar modal wajib terlebih dahulu terdaftar di Bapepam dan LK. Profesi penunjang terdiri dari akuntan publik, notaris, konsultan hukum dan perusahaan penilai.

Pihak Lain Yang Terlibat, merupakan pihak-pihak lain yang juga terlibat dalam pelaksanaan penawaran umum obligasi daerah di pasar modal, namun tidak terlibat secara langsung dalam 
proses transaksi perdagangan efek, yang terdiri dari penyedia penguatan kredit, lembaga pemeringkat efek serta penasihat investasi.

a) Lembaga Pemeringkat Efek, merupakan lembaga yang memberikan peringkat kredit bagi penerbit obligasi daerah. Lembaga pemeringkat mengukur kelayakan kredit, kemampuan membayar pinjaman yang akan mempengaruhi tingkat bunga pinjaman.

b) Penyedia Penguatan Kredit, adalah pihak yang memberikan penguatan kredit melalui pernyataan kesediaan menjamin obligasi daerah, dimana penguatan kredit ini akan memberikan kenyamanan bagi investor dan dapat mempengaruhi tingkat bunga.

c) Penasihat Investasi, merupakan pihak yang memberikan nasihat kepada pihak lain berkaitan dengan penjualan atau pembelian efek dengan memperoleh imbalan jasa.

Selanjutnya, obligasi daerah sebagai sumber pinjaman yang akan diperjual belikan di pasar modal, maka penerbitan obligasi daerah pun harus memenuhi semua ketentuan yang berlaku di pasar modal, sebagaimana diatur pada Undang-Undang No. 8 Tahun 1995 tentang Pasar Modal. Salah satu bentuk pinjaman yang dapat diperoleh Pemerintah Daerah adalah dengan menerbitkan obligasi (municipal bond). Berdasarkan UndangUndang No. 8 Tahun 1995 tentang Pasar Modal, menerangkan bahwa, obligasi merupakan:
1. Sebuah bentuk alternatif instrumen/efek/surat berharga yang dipakai untuk bukti berhutang/mendapat pendanaan dari sumber lain,

2. Dapat diperjual belikan di pasar modal,

3. Harus dijaminkan oleh penanggung untuk pemenuhan janji yang meliputi pengembalian pokok, bunga (coupon) dan janji lainnya pada saat jatuh tempo,

4. Dapat diterbitkan oleh pemerintah (Pusat dan Daerah) dan perusahaan berbadan hukum (BUMN dan Swasta)

Penerbitan obligasi daerah diharapkan akan memberikan banyak manfaat, baik Pemerintah Daerah sebagai pihak emiten, masyarakat luas sebagai sarana investasi, begitu juga bagi masyarakat daerah yang mendapatkan manfaat dari pembangunan yang pendanaannya melalui penerbitan obligasi daerah. Budi. S. Purnomo mencatat terdapat beberapa manfaat penerbitan obligasi, antaralain:

1. Membiaya defisit anggaran

Pemerintah Daerah dapat memenuhi ketidakcukupan sumber pembiayaan sendiri yang diakibatkan oleh lemahnya local tax income, minimnya dana transfer dari pemerintah pusat, keterbatasan pinjaman dari lembaga keuangan dalam atau luar negeri.

2. Sumber dana jangka panjang 
Pemerintah Daerah mendapatkan sumber pembiayaan jangka panjang yang dapat disesuaikan dengan kebutuhan pembangunan, potensi serta kemampuan membayarnya, yang pada akhirnya akan membawa kemakmuran bagi masyarakat di didaerah.

3. Membiayai suatu proyek yang bersifat strategis

Dana hasil penjualan obligasi daerah dapat digunakan untuk membiayai proyek-proyek yang bersifat strategis untuk kepentingan pelayanan public atau mendatangkan pendapatan bagi Pemerintah Daerah, yang karena keterbatasan anggaran tidak dapat dibiayai oleh APBD.

4. Percepatan pembangunan daerah

Pemerintah Daerah dapat memicu dan memacu pembangunan di daerahnya. Pembangunan tersebut akan menciptakan multiplier effect (pelipatgandaan manfaat ekonomi), antara lain dalam bentuk penciptaan lapangan dan kesempatan kerja, tersediannya sarana dan prasarana yang dapat mempercepat perputaran roda perekonomian sehingga akan meningkatkan kesejahteraan masyarakat.

5. Perdayaan potensi ekonomi daerah

Potensi ekonomi daerah dan komoditi unggulan baik hayati (pertanian, perkebunan, perikanan, perhutanan dan peternakan dan non hayati (pertambangan dan minyak) dapat diberdayakan.

6. Transparansi dan Akuntabilitas
Setiap Pemerintah Daerah yang (akan) menerbitkan obligasi daerah, selain harus mematuhi semua peraturan yang ditetapkan oleh pemerintah pusat juga harus memenuhi seluruh ketentuan dari BAPEPAM-LK sebagai regulator pasar modal. Kepatuhan Pemerintah Daerah atas berbagai ketentuan BAPEPAM-LK tersebut akan mendorong Pemerintah Daerah untuk lebih meningkatkan transparansi dan akuntabilitasnya, khususnya dalam pengelolaan dan pelaporan keuangan.

7. Meningkatkan ekspose daerah Penerbitan obligasi daerah akan menambah jumlah pihak-pihak yang berkepentingan dengan usaha Pemerintah Daerah khususnya dalam penyelenggaraan kegiatankegiatan yang dibiayai dengan dana yang bersumber dari penjualan obligasi daerah. Kepada para stakeholders tersebut Pemerintah Daerah berkewajib untuk menyampaikan laporan yang dengan sendirinya akan meningkatkan ekspose Pemerintah Daerah, baik atas usaha yang telah dilakukan maupun potensi ekonomi lain yang dimiliki daerah.

8. Meningkatkan image/prestige daerah

Keberhasilan daerah dalam memasarkan obligasi daerah mencerminkan kepercayaan 
masyarakat investor yang akan meningkatkan prestige daerah tersebut.

9. Terciptanya instrumen investasi baru

Adanya obligasi daerah, selain memberikan manfaat langsung dengan dibangunnya infrastruktur, masyarakat juga dapat menikmati imbal hasil (yield) dan mungkin juga insentif lain atas investasinya dalam obligasi daerah.

10. Merupakan lahan baru bagi lembaga atau profesi yang bermain di pasar modal (Purnomo, 2009).

Dengan beberapa fungsi yang dapat diambil dengan diterbitkannya obligasi daerah, maka Pemerintah Daerah harus mampu mempersiapkan rencana pembangunan yang berkesinambungan, baik perencanaan jangka pendek, menengah maupun panjang. Pemerintah Daerah juga harus mempersiapkan potensi risiko-risiko yang dihadapi dengan rencana-rencana penyelesaian yang matang. Untuk menarik minat para investor agar membeli Obligasi Daerah yang ditawarkan di pasar modal, Pemerintah

\section{Simpulan}

Menerbitkan Obligasi Daerah merupakan sebagai salah satu alternatif pendanaan bagi Pemerintah Daerah guna merealisasikan pembangunan di Daerah. Obligasi daerah juga membuka peluang bagi masyarakat di Daerah pada khususnya untuk ikut berpartisipasi berinvestasi. Perencanaan yang matang merupakan awal kegagalan dan kesuksesan dari diterbitkannya obligasi daerah, sehingga Pemerintah Daerah harus
Daerah harus benar-benar memberikan kepastian bahwa obligasi tersebut akan dibayarkan kembali pada saat jatuh tempo. Mengingat bahwa Obligasi Daerah dipergunakan untuk proyek yang memberikan manfaat kepada publik dan menghasilkan penerimaan, maka proyek tersebut harus benar-benar matang dan layak. Oleh karena itu, dalam tahapan sebelum mendapat persetujuan dari menteri keuangan, Studi Kelayakan harus dibuat oleh lembaga penilai yang terdaftar di Bapepam-LK sehingga hasilnya dapat dipertanggungjawabkan. Kesiapan pemerintah merupakan modal awal tercapainya maksud dan tujuan diterbitkan obligasi daerah, maupun bagi pemangku kepentingan yang lain. Dalam dunia bisnis kita mengenal trust sebagai modal awal suatu hubungan bisnis dapat tercapai, trust memberikan multiplier effect yang positif bagi Pemerintah Daerah kedepan dalam rangka pembangunan dan mensejahterkan masyarakat di daerah pada khususnya.

selalu memiliki persiapan yang matang menghadapi segala kemungkinan risiko selain itu juga menjaga trust dari masyarakat.

\section{Daftar Pustaka}

Islamy, M. Irfan., 2009, PrinsipPrinsip Perumusan Kebijakan Negara, cetakan ke 15, Jakarta: PT Bumi Aksara.

Knopf, Alfred. A., 1999, Development as Freedom, New York. 
Purnomo, Budi. S., 2009, Obligasi Daerah (Alternatif Investasi bagi Masyarakat dan Sumber Pendanaan bagi Pemerintah Daerah, Bandung: Penerbit ALFABETA.

Sugianto, Fajar., 2013, Economic Approach to Law, Seri Analisis Ke-ekonomian Tentang Hukum, Penerbit Kencana Prenada Media Group, Jakarta.

Analysis of Law Penerbit
Kencana Prenada Media Group,
Jakarta.

Sorensen, George., 1993, Democracy and Democratization: Processes and Prospects in a Changing World, Terjemahan oleh I Made Krisna, 2003, Yogyakarta: Penerbit Pustaka Pelajar.

Tjandra, W. Riawan., 2004, Dinamika Peran Pemerintah Dalam Perspektif Hukum Administrasi (Analisis Kritis Terhadap Perspektif Penyelenggaraan Pemerintahan), Yogyakarta: Penerbit Universitas Atma Jaya.

Yudhatama, Iranda., 2007, Demokrasi Overdosis, Menggugat tanggungjawab negara atas jaminan sosial kesehatan dalam system demokrasi Liberal, Yogyakarta: Penerbit Pustaka Pelajar.

Widjaja, Gunawan \& Jono, 2006, Penerbitan Obligasi dan Peran serta Tanggung Jawab wali Amanat dalam Pasar Modal, Penerbit Kencana Prenada Media group, Jakarta.

\section{Makalah/Seminar}

Ringkasan Eksekutif Power, Welfare and Democracy (PWD) Project,
2014 "Demokrasi di Indonesia: Antara Patronase dan Populisme", kerjasama antara Universitas Gadjah Mada (Jurusan Politik dan Pemerintahan) dan University of Oslo serta didukung oleh The Royal Norwegian Embassy.

\section{Artikel dalam Jurnal}

Okta, Dewi dan Kaluge, David., 2011, Analisis Peluang Penerbitan Obligasi Daerah Sebagai Alternatif Pembiayaan Daerah, Journal of Indonesian Applied Economics, Vol. 5 No. 2 Oktober 2011: 157-171.

Lubis, Ade Zul Akhir., 2013, Analisis Pengaruh Pengeluaran Publik Terhadap Pembangunan (studi Kasus Pada Negara-Negara ASEAN4), Jurnal Ilmiah, Jurusan Ilmu ekonomi, Fakultas Ekonomi dan Bisnis Universitas Brawijaya, Malang 2013.

\section{Dokumen Resmi}

Tim Studi Penyusunan Draft Peraturan Mengenai Pedoman Penerbitan Obligasi Daerah, Studi Penyusunan Draft Peraturan Mengenai Pedoman Penerbitan Obligasi Daerah, Departemen Keuangan Republik Indonesia Badan Pengawas Pasar Modal Proyek Peningkatan Efisiensi Pasar Modal Tahun 2005. 
Pelengkap Buku Pegangan 2008, Penyelenggaraan Pemerintah dan Pembangunan Daerah, Departemen Keuangan Republik Indonesia, Direktorat Jenderal Perimbangan Keuangan Departemen Keuangan Mei 2008.

Panduan Penerbitan Obligasi Daerah, Direktorat Jenderal Perimbangan Keuangan Departemen Keuangan, 2007.
Tata Cara Penerbitan dan Pertanggungjawaban Obligasi Daerah, dapat diakses di: http://www.djpk.kemenkeu. go.id/produkhukum/peraturan-menterikeuangan/item/802-TataCara-Penerbitan-danPertanggungjawabanObligasi-Daerah di akses pada 24 Maret 2015, Pukul 23.00 WITA.

\section{Website}

